\title{
QUANTIFYING PELAGE COLORATION OF SOUTHEAST ASIA SPINY \\ RATS GENUS Maxomys (MURIDAE: RODENTIA) USING SPECTROPHOTOMETRIC MEASUREMENTS
}

\section{KUANTIFIKASI WARNA RAMBUT TIKUS DURI ASIA TENGGARA \\ DARI GENUS Maxomys (MURIDAE: RODENSIA) DENGAN PENGUKURAN SPEKTROFOTOMETRI}

\author{
Anang S. Achmadi ${ }^{1 *}$, Hitoshi Suzuki ${ }^{2}$ \\ ${ }^{1}$ Museum Zoologicum Bogoriense, Research Center for Biology, Cibinong, Indonesia \\ ${ }^{2}$ Graduate School of Environmental Science, Hokkaido University, Sapporo 060-0810 Japan \\ E-mail: gudelly@gmail.com
}

(diterima Mei 2018, direvisi Agustus 2018, disetujui November 2018)

\begin{abstract}
ABSTRAK
Kami mendokumentasikan kajian pendahuluan tentang variasi warna rambut pada Maxomys, salah satu jenis tikus yang umum di Asia Tenggara. Kami menggunakan spesimen kulit yang sebagian besar disimpan di Museum Zoologicum Bogoriense, Indonesia. Pengukuran kuantitatif warna rambut yang dilakukan dengan menggunakan spektrofotometer menunjukkan tidak adanya perbedaan yang signifikan pada warna rambut bagian punggung atau dorsal, yang sebagian besar berwarna coklat tua $\left(L^{*}=25-30, a^{*}=5-7, b^{*}=10-15\right)$. Warna rambut bagian perut atau ventral bervariasi pada masing-masing jenis. Kami mengklasifikasikan lima macam pola warna yang berbeda berdasarkan hasil pengukuran: abu-abu keputihan (M. baeodon, M. whiteheadi, M. musschenbroekii, M. bartelsii, dan $M$. dollmani), oranye coklat-gelap ( $M$. hylomyoides), oranye-kastanye ( $M$. ochraceiventer), coklat kekuningan (M. alticola) dan putih krem (M. rajah, M. hellwaldii, dan M. surifer). Karakteristik pola warna rambut ini dapat dipergunakan dalam pengenalan spesies, bersamaan dengan karakter tengkorak kepala. Selanjutnya, kajian molekuler terhadap variasi warna rambut pada Maxomys spp. sangat diperlukan untuk mengetahui mekanisme variasi fenotipik pada morfologi jenis ini yang dapat mempengaruhi pola penyebaran, spesiasi dan sejarah evolusi dari Maxomys. Kajian ini belum berhasil mendapatkan sekuens dari Maxomys menggunakan gen Mclr (melanocortin-1 receptor), dan mungkin akan lebih baik jika menggunakan gen lain seperti gen ASIP (agouti signaling peptide).
\end{abstract}

Kata kunci: variasi warna rambut, pengukuran kuantitatif, Maxomys, spektrofotometer .

\begin{abstract}
We documented preliminary study of coat color variations within Maxomys, one of the most common rats in the Southeast Asian region. We sampled the skin specimens that mostly deposited at Museum Zoologicum Bogoriense, Indonesia. Quantitative measurements of coat color using spectrophotometer revealed no significant difference in the dorsal pelage showing mostly dark brown $\left(L^{*}=25-30, a^{*}=5-7, b^{*}=10-15\right)$. The ventral colorations were variable among the species. We classified five different color types based on the measurements: whitish grey (M. baeodon, M. whiteheadi, M. musschenbroekii, M. bartelsii, and M. dollmani), orange dark brown (M. hylomyoides), chestnut orange (M. ochraceiventer), yellowish brown (M. alticola) and creamy white (M. rajah, M. hellwaldii, and M. surifer). These fur color characteristics can be useful in species recognition, together with the craniometric features. Furthermore, molecular study of coat color variation within Maxomys spp. is needed to elucidate the mechanisms of phenotypic variation in morphology that affect the patterns of divergence, speciation and evolutionary history of Maxomys. Here, we failed to obtain the sequences from Maxomys using Mc1r (melanocortin-1 receptor) gene, and probably will be better to use other gene such as ASIP (agouti signaling peptide) gene.
\end{abstract}

Keywords: coat color variations, quantitative measurements, Maxomys, spectrophotometer.

\section{INTRODUCTION}

Mammalian pelage coloration plays important roles in crypsis, intraspecific communication, thermoregulation, predation avoidance and ultraviolet screening (Endler 1990; Caro 2005; Lai et al. 2008). Pelage coloration is an important phenotypic character as a result of individual adaptations to its environments and living with other animals. Adaptive significance of coloration in animals can be explained by several selective forces (Burtt 1981; Cloudsley-Thompson 1999). The color patterns of animals and their visual backgrounds may be regarded as mosaics of patches which vary in size, shape, brightness and color (Endler 1990). 
Hypothetically, the different parts of the body in different mammal species are subject to several selective pressures, and pelage coloration represents as a great adaptive importance (Caro 2005).

In mammals, many of the working hypotheses regarding to the adaptive value of coat color was proposed more than 100 years ago and progressed little since then (Caro 2005). Recently, these hypotheses have attracted interest, and are again being explored and tested (e.g. Ortolani 1999; Stoner et al. 2003a, 2003b; Nachman 2005; Hoekstra 2006; Hoekstra et al. 2006). The three most important adaptive functions of pelage are concealment, communication, and thermoregulation (Cott 1940; Caro 2005; Lai et al. 2008). Previous studies have been conducted related to adaptive functions of pelage coloration in mammals: e.g., changing visual characteristics in order to minimize predator detection (Rowland 2009), inconspicuous or cryptic color patterns against visual background (Endler 1990; Ortolani 1999), and as thermoregulatory properties (Burtt 1981; Walsberg 1983).

Until recently, the validity of mammal pelage coloration as a diagnostic tool for species identification is still a problem. Endler (1990) stated there were five major weaknesses related to color determination on wildlife animal: 1) human subjectivity, 2) the adjacent color patches that can affect the perceived color of a patch, 3) lighting conditions, 4) the variation among normal people, and 5) the differences in a vision between humans and animals which the color patterns are directed. Despite matching with Munsell soil color chart (Lai et al. 2008), there is no quantitative standard color measurements in order to determine the color patterns.
Murines, one of dominant groups of small mammals represented by more than 2000 species in the world, have various kinds of pelage colorations and play an important role in ecosystem. It can be a good sample to study the variations of pelage color patterns on mammals. Previously, studies of color variations have been conducted in murines based on morphology (Hoekstra 2006; Lai et al. 2008; Rios and Alvarez-Castaneda 2011; Salinas et al. 2015) and evolutionary history or molecular phylogeny (Lovet et al. 1986; Montagutelli 2000; Shimada et al. 2009; Hubbard et al. 2010; Kambe et al. 2011; Kodama et al. 2015).

Within Southeast Asian murine populations, a genus Maxomys is known as one of the genera with widespread distributions start from mainland of SE Asia (Thailand, Vietnam, Malaysia) until Philippines and Indonesia. They also have various color variations and still there is no information about color variations based on morphology or molecular phylogeny. In this preliminary study, we documented an inventory of coat color variations within Maxomys, mostly from skin specimens deposited at Museum Zoologicum Bogoriense, Indonesia.

\section{MATERIALS AND METHODS}

We measured 70 skins of Maxomys (Appendix 1): M. hellwaldii, $\quad M$. musschenbroekii, M. dollmani, M. rajah, $M$. surifer, M. baeodon, M. ochraceiventer, M. whiteheadi, M. alticola, M. pagensis, $M$. hylomyoides, and M. bartelsii. All color measurements were made on adults. Singaravelan et al. (2013) noted that the coloration changes during the course of ageing; pups and juveniles were lighter than fully matured adults. We measured the dorsal and ventral pelage colors using a digital colorimeter 


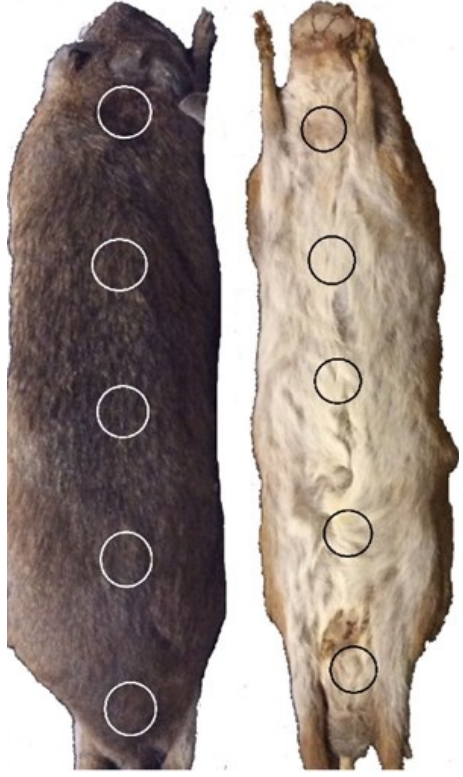

Figure 1. Photograph of a specimen of Maxomys sp. showing the five points over the dorsal and ventral body region, namely the neck, upper back, middle back, lower back, and rump, where we measured the pelage color.

(Spectrofotometer CM-700D, KONICA MINOLTA).

Each animal was measured at least 5 times shaping line posteriorly (Figure 1). We used the $\mathrm{L}^{*} \mathrm{a} * \mathrm{~b} *$ color space model under standard daylight illumination (Hunter 1948) to quantify different components of the measured color from both SCI and SCE techniques. We used SCI and SCE simultaneously from spectrophotometer and the color measurements based on specular reflectants (included or excluded). The color space component ' $\mathrm{L}^{*}$ ' represents the level of lightness in color $\left(\mathrm{L}^{*}\right.$ estimates equivalent to 'brown to black' eumelanin), a positive value of ' $a$ *' was represented in red/magenta, while a negative value of ' $a$ ' ' was represented in green. The positive value of ' $b$ '' was represented by the amount of purplish-red (magenta) yellow, while the negative value of ' $b$ *' represented by blue $\left(a^{*}\right.$ and $b^{*}$ estimates were equivalent to the 'yellow to red' pheomelanin). To further characterize the coat color, principal components analysis (PCA) was used to reduce the $\mathrm{L}^{*} \mathrm{a} \mathrm{b}^{*}$ color space model into a single component (PC) that represents the largest proportion of variation in coat color and lightness of the coat color using SPSS Inc.(2007). The authors also used canonical discriminant functions (DFA) to test the variables that give strong influences on the variance of variables.

\section{RESULTS AND DISCUSSION Results}

\section{Descriptive analysis}

Mean and standard deviation from the color measurements of Maxomys spp. are presented in Table 1. Overall, the dorsal coat coloration depicted less variations than ventral coat color in the Maxomys spp. that we examined. Throughout most of their range, dorsal pelage from the specimens are mostly dark brown (ranged from $L^{*}=25-30, a^{*}=5-7$, $\mathrm{b}^{*}=10-15$, see Table 1), individual hairs are banded, grey in the bases and brown to dark brown until the hair tip (Figure 2a). For ventral color, we detected five different color variations: ranged from whitish grey (ranged from $L^{*}=60-70, a^{*}=1-4, b^{*}=13-15 ; M$. baeodon, M. whiteheadi, M. bartelsii and $M$. dollmani), orange dark brown (ranged from $\mathrm{L}^{*}=40-58, \mathrm{a}^{*}=4-8, \mathrm{~b}^{*}=12-25$; M. hylomyoides), chestnut orange (ranged from $L^{*}=44-60, a^{*}=4-11, b^{*}=14-26$ M. ochraceiventer), yellowish brown $\left(\mathrm{L}^{*}=50\right.$ $-65, \mathrm{a}^{*}=5-9, \mathrm{~b}^{*}=24-31 ;$ M. alticola) and creamy white $\left(\mathrm{L}^{*}=45-88, \mathrm{a}^{*}=-0.4-15\right.$, $\mathrm{b}^{*}=5-35 ; M$. rajah, M. hellwaldii and $M$. surifer) (Figure $2 \mathrm{~b}$ and Table 2). As typical for many rodents, individual hairs of this part were mostly uniform color on each variation. 
Zoo Indonesia 2018 27(2): 99-111

Quantifying pelage coloration of Southeast Asia spiny rats genus Maxomys (Muridae; Rodentia) using spectrophotometric measurements

Table 1. Descriptive analysis: mean, number of specimens, standard deviation, maximum and minimum values of dorsal color measurements.

\begin{tabular}{|c|c|c|c|c|c|c|c|}
\hline \multirow{2}{*}{ Species } & & \multicolumn{3}{|c|}{ SCI } & \multicolumn{3}{|c|}{ SCE } \\
\hline & & $\mathrm{L}^{*}$ & $a^{*}$ & $\mathrm{~b}^{*}$ & $\mathrm{~L}^{*}$ & $\mathrm{a}^{*}$ & $\mathrm{~b}^{*}$ \\
\hline \multirow[t]{4}{*}{ Maxomys hellwaldii } & Mean & 28.98 & 6.56 & 12.64 & 28.81 & 6.60 & 12.77 \\
\hline & Min & 25.73 & 4.35 & 8.88 & 25.54 & 4.36 & 8.98 \\
\hline & $\operatorname{Max}$ & 34.49 & 9.76 & 19.17 & 34.52 & 9.82 & 19.33 \\
\hline & Stdev & 2.41 & 1.85 & 3.30 & 2.48 & 1.86 & 3.31 \\
\hline \multirow[t]{4}{*}{ Maxomys musschenbroekii } & Mean & 26.17 & 4.23 & 9.08 & 26.16 & 4.24 & 9.16 \\
\hline & Min & 20.43 & 2.25 & 4.38 & 21.19 & 2.29 & 4.47 \\
\hline & Max & 33.42 & 7.97 & 18.88 & 33.34 & 7.96 & 18.85 \\
\hline & Stdev & 3.08 & 1.31 & 3.36 & 2.86 & 1.31 & 3.34 \\
\hline \multirow{4}{*}{ Maxomys pagensis } & Mean & 28.37 & 6.46 & 11.78 & 28.29 & 6.48 & 11.86 \\
\hline & Min & 21.74 & 2.92 & 5.04 & 21.71 & 2.93 & 5.12 \\
\hline & $\operatorname{Max}$ & 36.33 & 11.06 & 20.19 & 36.19 & 11.07 & 20.44 \\
\hline & Stdev & 4.19 & 2.25 & 4.38 & 4.19 & 2.27 & 4.39 \\
\hline \multirow[t]{4}{*}{ Maxomys bartelsii } & Mean & 28.37 & 5.85 & 10.00 & 28.31 & 5.86 & 10.06 \\
\hline & Min & 19.49 & 2.20 & 3.71 & 19.39 & 2.31 & 3.82 \\
\hline & Max & 35.03 & 8.42 & 17.28 & 35.06 & 8.63 & 17.58 \\
\hline & Stdev & 3.61 & 1.30 & 2.77 & 3.62 & 1.33 & 2.82 \\
\hline \multirow[t]{4}{*}{ Maxomys dollmani } & Mean & 27.72 & 3.78 & 7.51 & 27.64 & 3.80 & 7.56 \\
\hline & Min & 24.23 & 2.90 & 5.84 & 24.20 & 2.91 & 5.91 \\
\hline & $\operatorname{Max}$ & 31.19 & 5.05 & 9.57 & 31.01 & 5.11 & 9.60 \\
\hline & Stdev & 2.72 & 0.79 & 1.34 & 2.59 & 0.81 & 1.33 \\
\hline \multirow[t]{4}{*}{ Maxomys baeodon } & Mean & 25.49 & 6.03 & 10.04 & 25.46 & 6.04 & 11.71 \\
\hline & Min & 18.19 & 4.05 & 5.78 & 18.67 & 3.98 & 5.79 \\
\hline & Max & 32.69 & 8.64 & 14.74 & 32.49 & 8.63 & 71.05 \\
\hline & Stdev & 3.17 & 1.29 & 2.60 & 3.01 & 1.31 & 9.97 \\
\hline \multirow[t]{4}{*}{ Maxomys alticola } & Mean & 26.04 & 6.74 & 11.84 & 25.97 & 6.76 & 11.89 \\
\hline & Min & 22.15 & 5.11 & 8.49 & 22.19 & 5.13 & 8.55 \\
\hline & Max & 33.65 & 8.78 & 18.07 & 33.66 & 8.93 & 18.16 \\
\hline & Stdev & 3.61 & 1.13 & 2.93 & 3.58 & 1.16 & 2.95 \\
\hline \multirow[t]{4}{*}{ Maxomys ochraceiventer } & Mean & 26.93 & 5.72 & 9.81 & 26.87 & 5.75 & 9.91 \\
\hline & Min & 22.89 & 4.05 & 6.62 & 22.72 & 4.08 & 6.57 \\
\hline & Max & 32.69 & 7.66 & 13.94 & 32.49 & 7.69 & 14.01 \\
\hline & Stdev & 3.05 & 1.16 & 2.57 & 3.06 & 1.20 & 2.66 \\
\hline \multirow[t]{4}{*}{ Maxomys rajah } & Mean & 29.67 & 7.31 & 13.12 & 29.59 & 7.33 & 13.18 \\
\hline & Min & 23.45 & 4.23 & 7.49 & 23.42 & 4.21 & 7.71 \\
\hline & Max & 38.10 & 12.37 & 23.36 & 38.03 & 12.35 & 23.33 \\
\hline & Stdev & 3.63 & 1.97 & 3.83 & 3.64 & 1.98 & 3.84 \\
\hline \multirow[t]{4}{*}{ Maxomys surifer } & Mean & 31.46 & 7.84 & 14.61 & 31.40 & 7.87 & 14.70 \\
\hline & Min & 25.90 & 4.01 & 7.63 & 25.83 & 4.00 & 7.71 \\
\hline & Max & 36.68 & 11.86 & 22.94 & 36.66 & 11.85 & 22.91 \\
\hline & Stdev & 3.06 & 2.03 & 3.40 & 3.02 & 2.03 & 3.39 \\
\hline \multirow[t]{4}{*}{ Maxomys whiteheadi } & Mean & 24.53 & 5.91 & 9.84 & 24.55 & 5.91 & 9.79 \\
\hline & Min & 13.93 & 2.04 & 2.99 & 17.05 & 2.13 & 3.22 \\
\hline & Max & 32.53 & 10.84 & 27.39 & 32.41 & 10.87 & 18.29 \\
\hline & Stdev & 3.79 & 2.22 & 4.23 & 3.66 & 2.23 & 3.91 \\
\hline
\end{tabular}




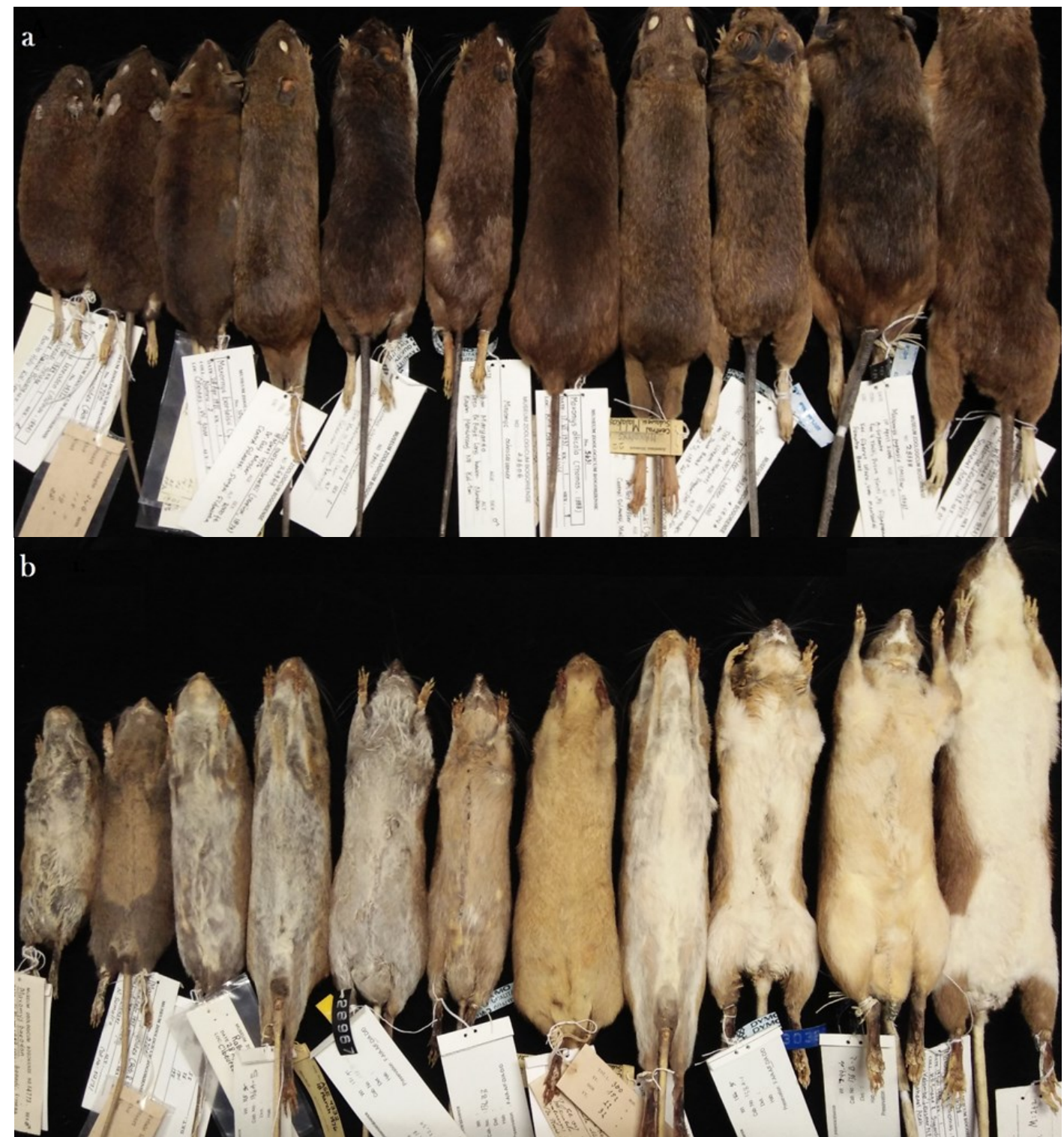

Figure 2. Representative variation in coat color (a. dorsal pelage and b. ventral pelage) among species of Maxomys spp.

\section{PCA and DFA analyses}

We described color variations using Principal Component Analysis (PCA) from the dependent variables (color variables) and extracted into three components in both dorsal and ventral coloration. We explained a total of $99.28 \%(\mathrm{PC} 1=75.38 \%$; $\mathrm{PC} 2=23.06 \%$; and $\mathrm{PC} 3=0.83 \%)$ of the variance in dorsal, and $99.09 \%(\mathrm{PC} 1=82.22 \%$; $\mathrm{PC} 2=14.83 \%$; and $\mathrm{PC} 3=2.04 \%$ ) of the variance in ventral color $(\mathrm{F}<0.05)$. We run the DFA for all variables in dorsal and ventral color, and detected that in dorsal color variables $\mathrm{L}^{*}$ (lightness) and a* if specular components included (SCI) give strong influence to the variations with total of $100 \%$ variance extracted from 3 discriminant functions (Function $1=71.2 \%$; Function $2=$ $17.5 \%$; and Function $3=11.3 \%$; $<<0.001$; df $=33$ ). For ventral color, We detected variable $\mathrm{L}^{*}$ with specular component included (SCI) and $b^{*}$ with specular component excluded (SCE) as the main variables that give most significant influence with a total variations of $100 \%$ extracted from two functions (Function 
Zoo Indonesia 2018 27(2): 99-111

Quantifying pelage coloration of Southeast Asia spiny rats genus Maxomys (Muridae; Rodentia) using spectrophotometric measurements

Table 2. Descriptive analysis: mean, number of specimens, standard deviation, maximum and minimum values of ventral color measurements.

\begin{tabular}{|c|c|c|c|c|c|c|c|}
\hline \multirow{2}{*}{\multicolumn{2}{|c|}{ Species }} & \multicolumn{3}{|c|}{ SCI } & \multicolumn{3}{|c|}{ SCE } \\
\hline & & $\mathrm{L}^{*}$ & $\mathrm{a}^{*}$ & $b^{*}$ & $\mathrm{~L}^{*}$ & $\mathrm{a}^{*}$ & $b^{*}$ \\
\hline \multirow[t]{4}{*}{ Maxomys hellwaldii $(\mathrm{n}=3)$} & Mean & 66.99 & 2.48 & 18.95 & 67.10 & 2.45 & 19.10 \\
\hline & Min & 45.81 & 0.01 & 5.43 & 46.23 & -0.08 & 5.47 \\
\hline & $\operatorname{Max}$ & 81.72 & 6.11 & 34.79 & 81.46 & 6.12 & 34.84 \\
\hline & Stdev & 10.61 & 1.66 & 8.25 & 10.33 & 1.66 & 8.21 \\
\hline \multirow[t]{4}{*}{ Maxomys musschenbroekii $(\mathrm{n}=4)$} & Mean & 67.22 & 5.73 & 28.76 & 67.08 & 5.79 & 28.96 \\
\hline & Min & 55.82 & 1.33 & 19.54 & 55.70 & 1.35 & 19.72 \\
\hline & Max & 82.32 & 11.53 & 39.11 & 82.26 & 11.59 & 39.22 \\
\hline & Stdev & 6.33 & 2.33 & 4.49 & 6.40 & 2.39 & 4.60 \\
\hline \multirow[t]{4}{*}{ Maxomys pagensis $(\mathrm{n}=4)$} & Mean & 47.40 & 6.46 & 17.71 & 47.39 & 6.46 & 17.81 \\
\hline & Min & 41.06 & 4.41 & 12.09 & 41.35 & 4.41 & 12.18 \\
\hline & Max & 56.21 & 8.17 & 24.46 & 56.16 & 8.18 & 24.61 \\
\hline & Stdev & 4.38 & 1.37 & 3.77 & 4.28 & 1.38 & 3.77 \\
\hline \multirow[t]{4}{*}{ Maxomys bartelsii $(\mathrm{n}=7)$} & Mean & 65.73 & 1.62 & 13.17 & 65.67 & 1.60 & 13.25 \\
\hline & Min & 46.82 & -0.77 & 4.06 & 47.40 & -0.78 & 4.15 \\
\hline & $\operatorname{Max}$ & 85.12 & 5.60 & 26.67 & 84.90 & 5.05 & 26.62 \\
\hline & Stdev & 9.25 & 1.28 & 5.62 & 9.12 & 1.21 & 5.65 \\
\hline \multirow[t]{4}{*}{ Maxomys dollmani $(\mathrm{n}=1)$} & Mean & 70.16 & 1.10 & 13.41 & 69.98 & 1.11 & 13.52 \\
\hline & Min & 62.34 & 0.39 & 11.47 & 62.01 & 0.40 & 11.71 \\
\hline & Max & 77.74 & 2.25 & 14.85 & 77.68 & 2.29 & 14.94 \\
\hline & Stdev & 7.23 & 0.77 & 1.35 & 7.26 & 0.79 & 1.31 \\
\hline \multirow[t]{4}{*}{ Maxomys baeodon $(\mathrm{n}=6)$} & Mean & 59.67 & 2.29 & 13.50 & 58.40 & 2.30 & 13.64 \\
\hline & Min & 50.82 & 0.57 & 7.64 & 12.51 & 0.58 & 7.74 \\
\hline & Max & 68.32 & 5.47 & 21.65 & 68.26 & 5.47 & 21.73 \\
\hline & Stdev & 5.22 & 1.14 & 3.62 & 9.96 & 1.16 & 3.72 \\
\hline \multirow[t]{4}{*}{ Maxomys alticola $(\mathrm{n}=2)$} & Mean & 57.89 & 7.08 & 29.37 & 57.82 & 7.12 & 29.50 \\
\hline & Min & 50.75 & 5.30 & 24.81 & 50.78 & 5.33 & 24.94 \\
\hline & Max & 64.81 & 9.07 & 30.72 & 64.66 & 9.14 & 30.95 \\
\hline & Stdev & 4.23 & 1.16 & 1.81 & 4.18 & 1.17 & 1.82 \\
\hline \multirow[t]{4}{*}{ Maxomys ochraceiventer $(\mathrm{n}=1)$} & Mean & 52.54 & 8.07 & 20.88 & 52.63 & 8.10 & 21.02 \\
\hline & Min & 44.08 & 4.39 & 14.77 & 44.58 & 4.55 & 15.26 \\
\hline & Max & 59.05 & 10.72 & 25.37 & 58.86 & 10.73 & 25.41 \\
\hline & Stdev & 4.27 & 2.38 & 3.11 & 4.19 & 2.37 & 3.06 \\
\hline \multirow[t]{4}{*}{ Maxomys rajah $(\mathrm{n}=7)$} & Mean & 80.68 & 1.20 & 17.40 & 80.67 & 1.20 & 17.50 \\
\hline & Min & 72.12 & -0.40 & 12.77 & 72.35 & -0.38 & 12.89 \\
\hline & $\operatorname{Max}$ & 87.10 & 2.83 & 25.97 & 86.90 & 2.84 & 26.12 \\
\hline & Stdev & 3.35 & 0.81 & 3.47 & 3.20 & 0.80 & 3.46 \\
\hline \multirow[t]{4}{*}{ Maxomys surifer $(\mathrm{n}=5)$} & Mean & 74.55 & 3.55 & 24.21 & 74.50 & 3.56 & 24.35 \\
\hline & Min & 59.62 & -0.09 & 14.60 & 59.76 & -0.07 & 14.71 \\
\hline & Max & 86.17 & 15.02 & 35.18 & 85.96 & 15.06 & 35.32 \\
\hline & Stdev & 7.43 & 3.59 & 6.11 & 7.38 & 3.60 & 6.13 \\
\hline \multirow[t]{4}{*}{ Maxomys whiteheadi $(\mathrm{n}=23)$} & Mean & 60.32 & 3.67 & 14.64 & 60.26 & 3.85 & 14.88 \\
\hline & Min & 42.38 & 0.05 & 5.97 & 43.11 & 0.09 & 6.06 \\
\hline & $\operatorname{Max}$ & 78.44 & 12.64 & 30.37 & 78.13 & 20.14 & 30.43 \\
\hline & Stdev & 6.68 & 2.56 & 5.10 & 6.56 & 2.99 & 5.11 \\
\hline
\end{tabular}


Table 3. Total variance explained for dorsal color measurements of Maxomys from PCA analysis using correlation matrix.

\begin{tabular}{ccccccc}
\hline \multirow{2}{*}{ Component } & \multicolumn{3}{c}{ Initial Eigenvalues } & \multicolumn{3}{c}{ Extraction Sums of Squared Loadings } \\
\cline { 2 - 7 } & Total & $\begin{array}{c}\text { \% of } \\
\text { Variance }\end{array}$ & $\begin{array}{c}\text { Cumulative } \\
\%\end{array}$ & Total & $\begin{array}{c}\text { \% of } \\
\text { Variance }\end{array}$ & $\begin{array}{c}\text { Cumulative } \\
\%\end{array}$ \\
\hline 1 & 6.03 & 75.38 & 75.38 & 6.03 & 75.38 & 75.38 \\
2 & 1.85 & 23.07 & 98.45 & 1.85 & 23.07 & 98.45 \\
3 & 0.07 & 0.83 & 99.28 & 0.07 & 0.83 & 99.28 \\
\hline
\end{tabular}

Only cases for which Species_no $=12$ are used in the analysis phase.

Table 4. Total variance explained for ventral color measurements of Maxomys from PCA analysis using correlation matrix.

\begin{tabular}{ccccccc}
\hline \multirow{2}{*}{ Component } & \multicolumn{3}{c}{ Initial Eigenvalues } & \multicolumn{2}{c}{ Extraction Sums of Squared Loadings } \\
\cline { 2 - 7 } & Total & $\begin{array}{c}\text { \% of } \\
\text { Variance }\end{array}$ & $\begin{array}{c}\text { Cumulative } \\
\%\end{array}$ & Total & $\begin{array}{c}\text { \% of } \\
\text { Variance }\end{array}$ & $\begin{array}{c}\text { Cumulative } \\
\%\end{array}$ \\
\hline 1 & 6.58 & 82.22 & 82.22 & 6.58 & 82.22 & 82.22 \\
2 & 1.19 & 14.83 & 97.06 & 1.19 & 14.83 & 97.06 \\
3 & 0.16 & 2.04 & 99.10 & 0.16 & 2.04 & 99.09 \\
\hline
\end{tabular}

Only cases for which Species_no $=12$ are used in the analysis phase.

Table 5. Total explained variation for dorsal color measurements on two discriminant functions (DFs) using stepwise methods.

\begin{tabular}{ccccc}
\hline Function & Eigenvalue & \% of Variance & Cumulative \% & $\begin{array}{c}\text { Canonical } \\
\text { Correlation }\end{array}$ \\
\hline 1 & $1.741(\mathrm{a})$ & 71.2 & 71.2 & 0.797 \\
2 & $.428(\mathrm{a})$ & 17.5 & 88.7 & 0.548 \\
3 & $.276(\mathrm{a})$ & 11.3 & 100 & 0.465 \\
\hline
\end{tabular}

a. First 2 canonical discriminant functions were used in the analysis.

Table 6. Total explained variation for ventral color measurements on two discriminant functions (DFs) using stepwise methods.

\begin{tabular}{ccccc}
\hline Function & Eigenvalue & \% of Variance & Cumulative \% & $\begin{array}{c}\text { Canonical } \\
\text { Correlation }\end{array}$ \\
\hline 1 & $4.862(\mathrm{a})$ & 76.5 & 76.5 & 0.911 \\
2 & $1.493(\mathrm{a})$ & 23.5 & 100 & 0.774 \\
\hline
\end{tabular}

a. First 2 canonical discriminant functions were used in the analysis.

$1=76.5 \%$; and Function $2=23.5 \% ; \mathrm{P}<0.001 ;$ that clustered close to each other and $\mathrm{df}=22)($ Tables 3-6).

Scatter plots of PCA in dorsal color are mostly overlapped among species and supported by DFA using group centroid graph. Consistent to descriptive analysis, there is less variations on the dorsal color, even though we extracted nearly $100 \%$ variations from the dorsal color. In ventral color, from PCA and DFA scatter plots, we detected five groups consistent to descriptive analysis. First group of M. hellwaldii, M. surifer, and M. rajah were clustered close to each other, and some individuals were overlapped although group centroids are separated. Second group of M. musschenbroekii, M. baeodon, and $M$. whiteheadi stands closer than the other group, third group of M. pagensis and M. alticola, fourth group consist of $M$. bartelsii and $M$. 
dollmani, and fifth group of M. hylomyoides and $M$. ochraceiventer. Fifth group seems to be the most distinctive group due to ventral coloration, separated farthest from other groups (Figures 3, 4, 5, 6).
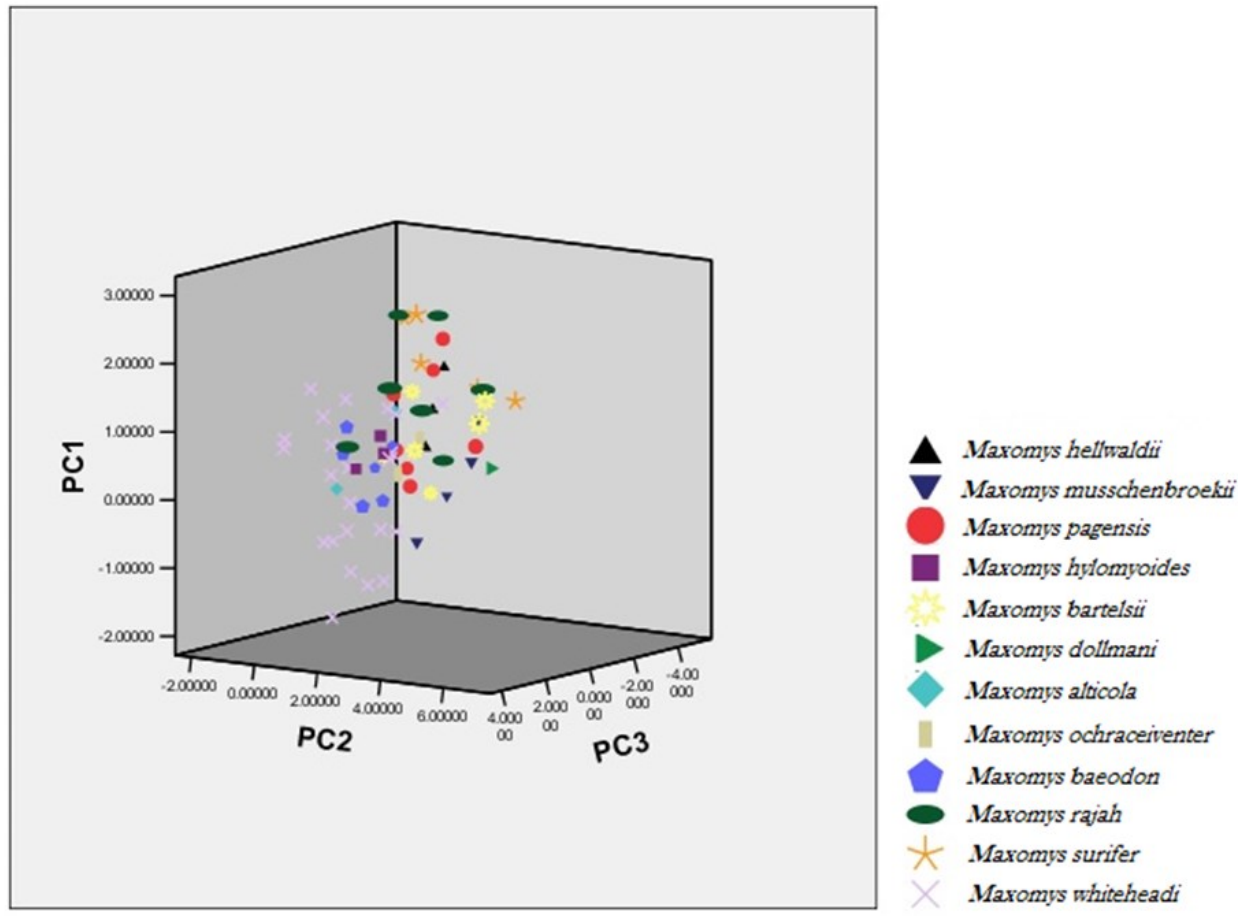

Figure 3. Three dimensional scatter plot from three components (PC1, PC2, and PC3) of PCA extracted from dorsal fur color variations among species of Maxomys spp.

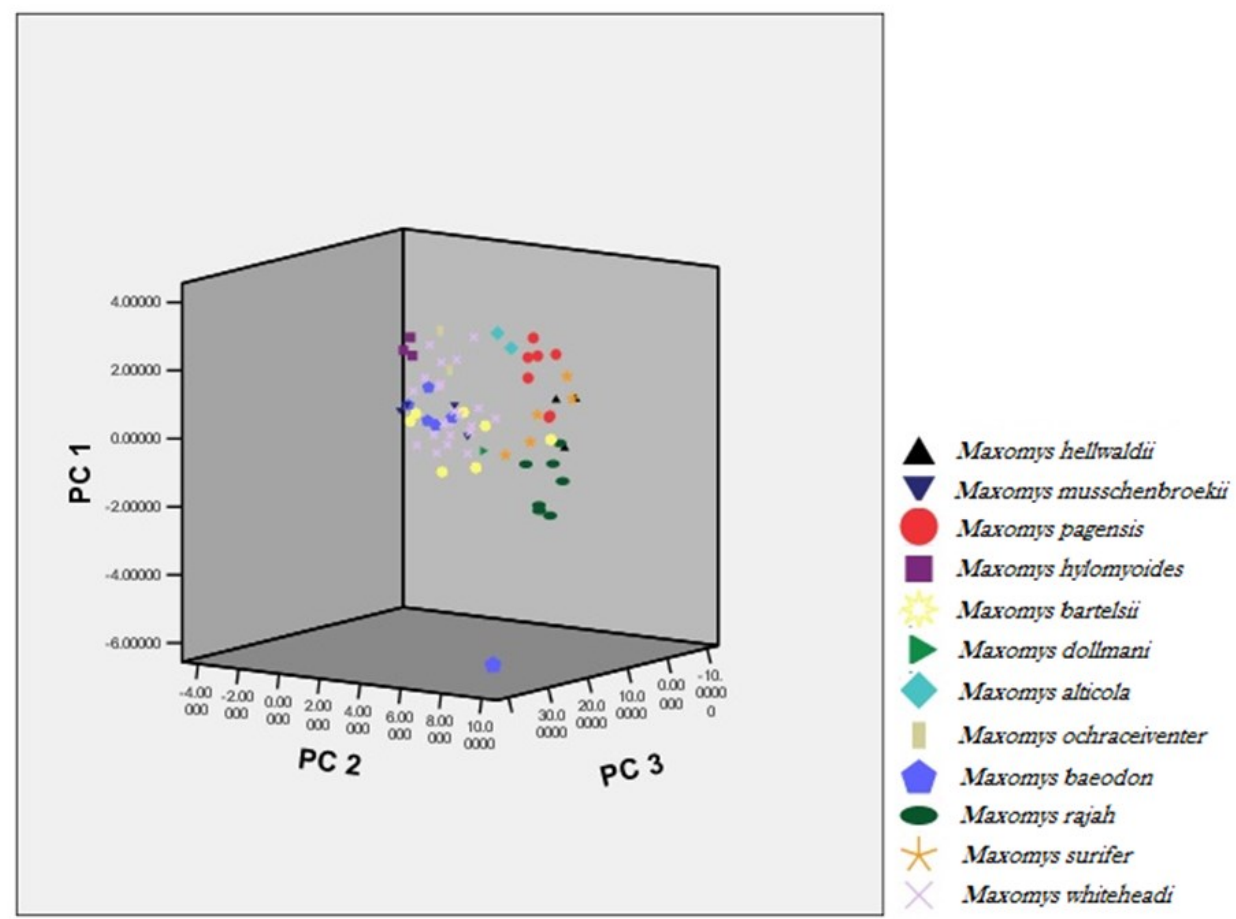

Figure 4. Three dimensional scatter plot from three components (PC1, PC2, and PC3) of PCA analysis that extracted from ventral fur color variations among species of Maxomys spp. 


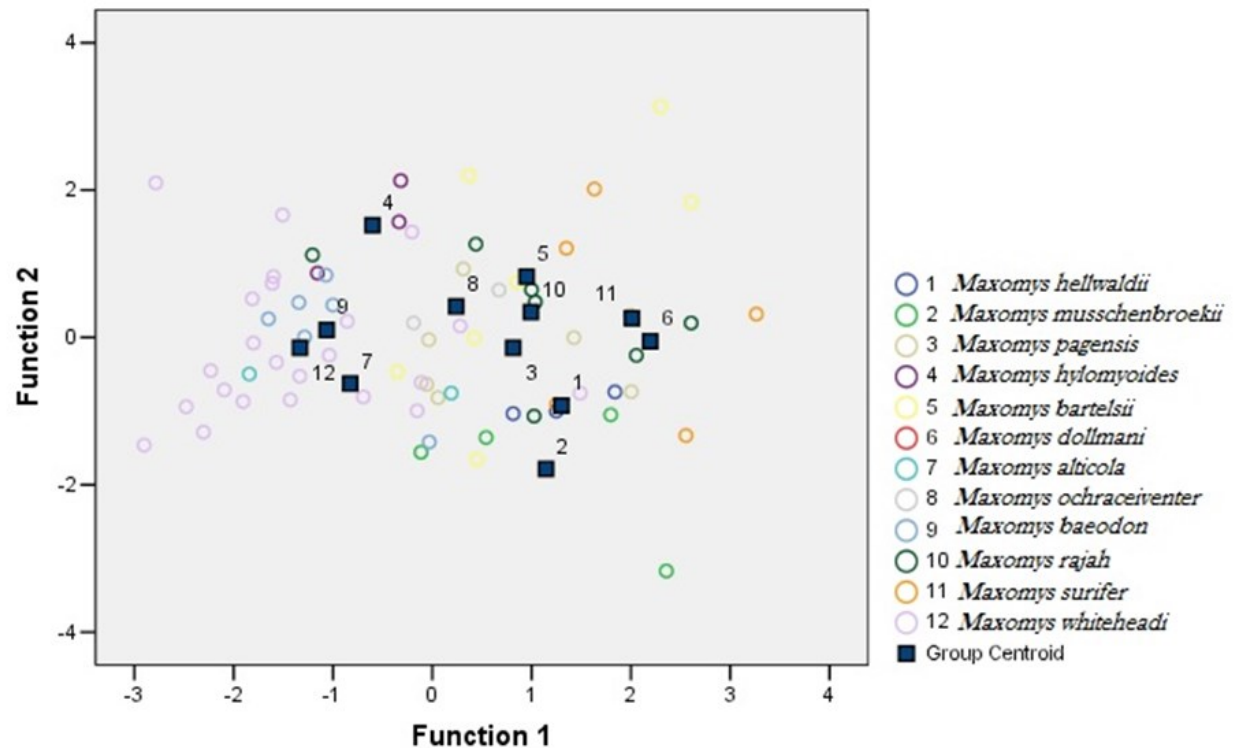

Figure 5. Plot of group centroid from DFA analysis (Function 1 and 2) among species of Maxomys based on dorsal coloration.

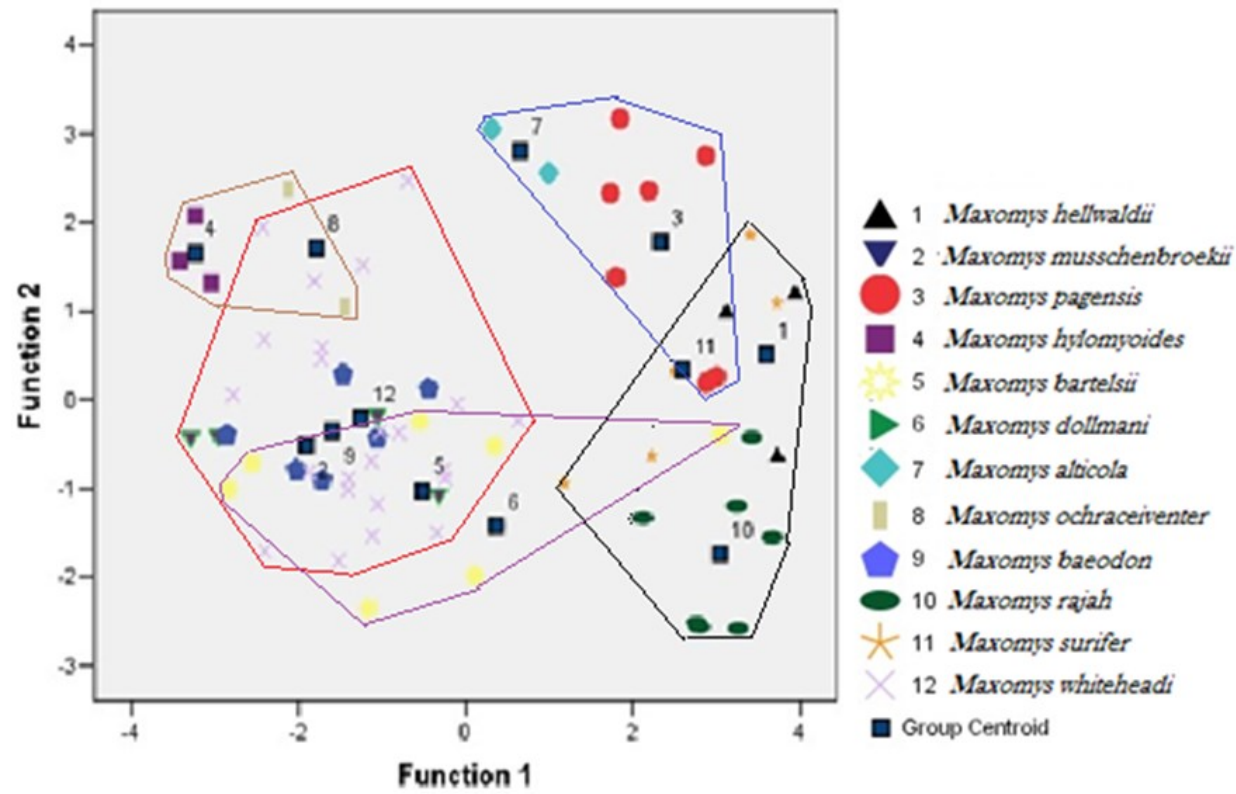

Figure 6. Plot of group centroid from DFA analysis (Function 1 and 2) among species of Maxomys based on ventral coloration.

\section{Discussion}

In mammals, especially murines, pelage coloration is one of the main key characters for species identification. Therefore, for some species pelage coloration used as the distinct features of the new species and descriptively determined in the monograph or in the diagnosis characters based on direct observation (Musser 1991, Pimsai et al. 2014). Otherwise quantitative information on color variation is very limited. In murines, few studies have been conducted to determine color variation based on quantitative analysis (Hoekstra \& Nachman 2003; Lai et al. 2008; 
Rios \& Alvarez-Castaneda 2011; Salinas et al. 2015). Additionally, some of researchers expand the studies into molecular works (Ounpraseuth et al. 2009; Lamoreux et al. 2010; Kambe et al. 2011; Kodama et al. 2015).

Our study aimed to generate preliminary information of quantitative color measurements that presented on Tables 1-2 and Figures 3-6. As a result, it is clear that for some species, the discrete pelage coloration on ventral color can be used as distinctive character. However, for few species the resemblance of color configuration among species may cause confusion related to identify the species, though these obstacles can be support with other main characters from other external characters or skull and dental characters.

In this study, we detected that the dorsal coloration of Maxomys ranged uniformly from brown to dark brown. This result consistent to Caro (2005) who mentioned that the uniform coloration were found in some mammals (artiodactyls, carnivores, and lagomorphs) in certain habitat likely the closed environment, tropical forest, dense forest or swamp forest. As we know, the natural habitat of Maxomys spp are found in the tropical forest (lowland until montane forest), disturbed forest and swamp forest. Generally, uniform pelage coloration in rodents provides protective camouflage, which is believed to be driven by the need to avoid detection by predators with the whole pelage matching the background where animals are active (Sumner 1921; Dice 1947; Lawlor 1976; Krupa \& Geluso 2000). However, we found more variations in ventral color (five significant lighter color than dorsum) from the specimens, this may because of counteract from the sun's effect (when it shines from above): lightening the dorsum and shading the ventrum (Thayer 1909, Kiltie 1988).

Recent study has demonstrating pelage color measurements using spectrophotometer to produce quantitative color variation among species of Maxomys spp. that can be useful for further research. Additionally, the observations of coat color variation have played an essential role in the understanding of many fundamental biological processes. Furthermore, molecular study of coat color variation within Maxomys spp. is needed to elucidate the mechanisms of phenotypic variation in morphology that affect the patterns of divergence, speciation and evolutionary history of Maxomys. We failed to obtain the sequences from Maxomys using Mclr (melanocortin-1 receptor) gene, and probably will be better to use other gene such as $A S I P$ (agouti signaling peptide) gene.

\section{CONCLUSION}

Here, we performed morphological analyses based on quantitative color measurements with specimens of Maxomys collected from throughout Indonesia from field works and those deposited at MZB. This quantitative measurements of coat color with a spectrophotometer revealed no significant difference in the dorsal pelage showing mostly dark brown $\left(\mathrm{L}^{*}=25-30, \mathrm{a}^{*}=5-7, \mathrm{~b}^{*}=10-15\right)$. The ventral colorations were variable among the species. We classified five different color types based on the measurements: whitish grey (M. baeodon, M. whiteheadi, M. musschenbroekii, M. bartelsii, and M. dollmani), orange dark brown 
(M. hylomyoides), chestnut orange ( $M$. ochraceiventer), yellowish brown (M. alticola) and creamy white (M. rajah, M. hellwaldii, and M. surifer). These fur color characteristics can be useful in species recognition, together with the craniometric features.

\section{ACKNOWLEDGEMENT}

This study would not have been possible without various administrative and financial support from JSPS Ronpaku PhD Dissertation Program and Hokkaido University as well. My deepest appreciation and gratitude to Dr. Jacob A. Esselstyn and Dr. Kevin C. Rowe for mentoring and supporting in everything, giving me an opportunity to collect specimens from Sulawesi since 2010 until now. I would also like to thank Prof. Dr. Ibnu Maryanto, Prof. Dr. Tajuddin Abdullah and Prof. Dr. James L. Patton for constructive comments. I would like to thank Prof. Dr. Masashi Ohara and Prof. Dr. Takashi Saitoh for their encouragement, comments and valuable suggestions.

I would also like to thank the Head of Museum Zoologicum Bogorience and Research Center for Biology for granting permission for continuing my postgraduate study, specimens and tissue loans for this study. I thanks to my labmates in Ecological Genetics Laboratory, especially to Satoko Mori and Gohta Kinoshita who helped me with laboratory works during my visits.

\section{REFERENCES}

Burtt, E. H. Jr. (1981). The adaptiveness of animal colors. Bioscience, 31, 723-729.

Caro, T. M. (2005). The adaptive significance of coloration in mammals. Bioscience,
$55,125-136$.

Cloudsley-Thompson, J. L. (1999). Multiple factors in the evolution of animal coloration. Naturwissenschaften, 86, 123132.

Cott, H. B. (1940). Adaptive colouration in animals. London: Metheun.

Dice, L. (1947). Effectiveness of selection by owls of deer mice (Peromyscus maniculatus) which contrast in color with their background. Contribution Laboratory Vertebrate Biology University of Michigan, 34, 1-20.

Endler, J. A. (1990). On the measurement and classification of color in studies of animal color patterns. Biological Journal of Linnean Society, 41, 315352.

Hoekstra, H. E. (2006). Genetics, development and evolution of adaptive pigmentation in vertebrates. Heredity, 97, 222-234.

Hoekstra, H. E. \& Nachman, M.W. (2003). Different genes underlie adaptive melanism in different populations of rock pocket mice. Molecular Ecology, $12,1185-1194$.

Hoekstra, H. E., Hirschmann, R.J., Bundey R.A., Insel, P.A. \& Crossland, J.P. (2006). A single amino acid mutation contributes to adaptive beach mouse color pattern. Science, 313, 101-104. doi: 10.1126/science.1126121.

Hubbard J.K, Uy, J.A., Hauber, M.E., Hoekstra, H.E. \& Safran, R.J. (2010). Vertebrate pigmentation: from underlying genes to adaptive function. Trends in Genetics, 26, 231-239.

Hunter, R.S. (1948). Photoelectric color difference meter. JOSA, 38, 661.

Kambe, Y., Nakata, K., Yasuda, S.P. \& 
Suzuki, H. (2011). Genetic characterization of Okinawan black rats showing coat color polymorphisms of white spotting and melanism. Genes and Genetic Systems, 87, 29 - 38.

Kiltie, R. A. (1988). Countershading: universally deceptive or deceptively universal? Trends in Ecological Evolution, 3, 21-23. doi:10. 1016/01695347(88)90079-1

Kodama, S., Nunome, M., Moriwaki, K. \& Suzuki, H. (2015). Data from: Ancient onset of geographical divergence, inter-population genetic exchange, and natural selection on the Mclr coat-colour gene in the house mouse (Mus musculus). Dryad Digital Repository. doi:10.5061/dryad.kt0s8.

Krupa, J.J. \& Geluso, K.N. (2000). Matching the color of excavated soil: cryptic coloration in the plains pocket gopher (Geomys bursarius). Journal of Mammalogy, 81, 86-96. doi:10.1644/1545-1542(2000)081 0086:MTCOE-SO2.0.CO;2

Lai, Y.C., Shiroishi, T., Moriwaki, K., Motokawa, M. \& Yu, H.T. (2008). Variation in coat color in house mice throughout Asia. Journal of Zoology London, 274, 270-276. doi:10. 1111/ j.1469-7998.2007.00382.x

Lamoreux, M.L., Delmas, V., Larue, L. \& Bennett, D.C. (2010). The Colors of Mice: A Model Genetic Network. A Wiley Blackwell Publishing Ltd. UK.

Lawlor, T.E. (1976). Coat Color Adaptations of Rodents Occurring on Lava BedsReanalysis of an Exceptional Case. Journal of Mammalogy, 57(2), 391-397. http://dx.doi.org/10.2307/1379703
Lovet, M., Cheng, Z., Lamela, E.M., Yokoi, T. \& Epstein, C.J. (1986). Molecular Markers for the agouti Coat Color Locus of the Mouse. Genetics, 115, 747-754.

Montagutelli, X. (2000). Effect of the Genetic Background on the Phenotype of Mouse Mutations. Journal of American Society of Nephrology, 11, S101-S105.

Musser, G.G. (1991). Sulawesi rodents: descriptions of new species of Bunomys and Maxomys (Muridae, Murinae). American Museum Novitates, 3001, 141.

Nachman, M.W. (2005). The genetic basis of adaptation: lessons from concealing coloration in pocket mice. Genetica, 123, 125-136.

Ortolani, A. (1999). Spots, stripes, tail tips and dark eyes: predicting the function of carnivore colour patterns using the comparative method. Biological Journal of Linnean Society, 67, 433-476.

Ounpraseuth, S., Rafferty, T.M., McDonaldPhillips, R.E., Gammill, W.M., Siegel, E.R., Wheeler, K.L., Nilsson, E. \& Cooney, C.A. (2009). A method to quantify mouse coat-color proportions. PLoS ONE, 4, 5414. http://dx.doi.org/10.1371/journal.

Pimsai, U., Pearch, M.J., Satasook, C., Bumrungsri, S. \& Bates, P.J.J. (2014). Murine rodents (Rodentia: Murinae) of the Myanmar-Thai-Malaysian peninsula and Singapore: taxonomy, distribution, ecology, conservation status, and illustrated identification keys. Bonn zoological Bulletin, 63(1), 15-114

Rios, E. \& Álvarez-Castañeda, S.T. (2012). Pelage color variation in pocket gophers (Rodentia: Geomyidae) in relation to 
sex, age and differences in habitat.

Mammalian Biology, 77(3), 160-165.

http://dx.doi.org/10.1016

j.mambio.2011.12.003.

Rowland, H.M. (2009). From Abbott Thayer to the present day: what have we learned about the function of countershading? Philosophical Transactions of the Royal Society of London. Series B, Biological Sciences, 364(1516): 519-527. http:// dx.doi.org/10.1098rstb.2008.0261.PMid :19000972.

Salinas, M.L.S., Barquez, R. M., Colombo, E.M. \& Sandoval, J.D. (2015). Intra-specific pelage color variation in a South American small rodent species. Brazilian Journal of Biology. http:// dx.doi.org/10.1590/1519-6984.00615

Shimada, T., Sato, J.J., Aplin, K.P., Suzuki, H. (2009). Comparative analysis of evolutionary modes in $M c 1 r$ coat color gene in wild mice and mustelids. Genes \& Genetic Systems, 84, 225-231.

Singaravelan, N., Raz, S., Tzur, S., Belifante, S., Pavlicek, T., Beiles, A., Ito, S., Wakamatsu, K. \& Nevo, E. (2013). Adaptation of pelage color and pigment variations in Israeli subterranean blind mole rats, Spalax ehrenbergi. PLoS One, 8(7): e69346. http:// dx.doi.org/10.1371/ journal.pone.0069346.PMid:23935991.

SPSS Inc. (2007). SPSS for Windows, version 13.0. Chicago: SPSS Inc.

Stoner, C.J., Bininda-Emonds, O.R.P. \& Caro, T.M. (2003a). The adaptive significance of coloration in lagomorphs. Biological Journal of Linnean Society of London, 79, 309-328.

Stoner, C.J., Caro, T.M. \& Graham, C.M. (2003b). Ecological and behavioral correlates of coloration in artiodactyls: systematic analyses of conventional hypotheses. Behavioral Ecology, 14, 823-840.

Sumner, F.B. (1921). Desert and lava-dwelling mice and the problem of protective coloration in mammals. Journal of Mammalogy, 2, 75-86.

Thayer, A. (1909). Concealing Coloration in the Animal Kingdom. New York: Macmillan.

Walsberg, G.E. (1983). Coat color and solar heat gain in animals. BioScience, 33, 88-91. doi:10.2307/1309169 